\title{
Belemnite-based strontium, carbon and oxygen isotope stratigraphy of the type area of the Maastrichtian Stage*
}

\author{
H.B. Vonhof ${ }^{1}{ }^{*}$, J.W.M. Jagt ${ }^{2}$, A. Immenhauser ${ }^{1}$, J. Smit ${ }^{1}$, Y.W. van den Berg ${ }^{3}$, M. Saher ${ }^{4}$, \\ N. Keutgen ${ }^{5}$ \& J.J.G. Reijmer ${ }^{1}$
}

1 Vrije Universiteit Amsterdam, Faculteit Aard- en Levenswetenschappen, De Boelelaan 1085, NL-1081 HV Amsterdam, the Netherlands.

2 Natuurhistorisch Museum Maastricht, de Bosquetplein 6-7, NL-6211 KJ Maastricht, the Netherlands.

3 TNO Built Environment and Geosciences, Princetonlaan 6, NL-3508 TA Utrecht, the Netherlands.

4 University of Plymouth, School of Geography, Earth and Environmental Sciences, 8 Kirkby Place, Drake Circus, Plymouth PL4 8AA, United Kingdom.

5 KFPBR, Uniwersytet Techniczno Bydgoszcz, ul. Bernardyńska 6/8, PL-85 029 Bydgoszcz, Poland.

* Corresponding author. Email: h.b.vonhof@vu.nl.

Manuscript received: October 2010, accepted: June 2011

\begin{abstract}
Belemnitellid cephalopods from the Maastrichtian stratotype area (southeast Netherlands) are shown to be comparatively well preserved. Although partial diagenetic alteration has been observed, micromilling techniques have permitted the extraction of pristine belemnite calcite, suitable for the reconstruction of strontium (Sr), oxygen (0) and carbon (C) isotope variation of Maastrichtian seawater. A distinct Sr isotope pattern in the Maastricht record can be matched stratigraphically with records from Hemmoor (northern Germany), El Kef (Tunisia) and 0DP site 690 (Maud Rise, Antarctica), leading to a new chemostratigraphical age model for the Maastrichtian stratotype section. Our data improve currently applied strontium isotope stratigraphical reference curves by revealing an Sr isotope inflection pattern near the lower/upper Maastrichtian boundary that is a potentially diagnostic feature for intra-Maastrichtian stratigraphical correlation between distant sections. Belemnites further show significant stratigraphical oxygen isotope variation through the Maastrichtian. We interpret this variation to have resulted from palaeoceanographic reorganisations in the Atlantic 0cean during this time interval.
\end{abstract}

Keywords: strontium isotope stratigraphy, Maastrichtian, type area, belemnites, diagenesis

\section{Introduction}

The Maastrichtian stratotype sequence in southern Limburg (the Netherlands; Fig. 1) predominantly comprises highly fossiliferous carbonate sediments, originally deposited in a shallow shelf sea (W.M. Felder, 1995; Jagt et al., 1996; Vonhof \& Smit, 1996; Schiøler et al., 1997). The prime section is that exposed at the ENCI-HeidelbergCement Group quarry. This comprises the Vijlen (upper portion), Lixhe 1-3 and Lanaye members (Gulpen Formation) as well as the Valkenburg, Gronsveld, Schiepersberg, Emael, Nekum and Meerssen members (Maastricht Formation), all of late Maastrichtian age. A wealth of shallow-water biota has been recovered from this quarry, including relatively complete mosasaur skeletons (Dortangs et al., 2002). The Maastrichtian stratotype, as originally defined, covers only the top part of the upper Maastrichtian interval as we now know it, and the quarry in which it was recorded nowadays extends down to approximately the lower/upper Maastrichtian boundary (Jagt, 2005, 2010). While the quarry section is comparatively well studied, current biostratigraphical zonations are still being refined and some uncertainties remain concerning correlations with other upper Maastrichtian sequences, such as those in northern Germany (e.g., Keutgen et al., 2010) and sequences in the United States (e.g., Jagt, 2005; Keutgen \& Jagt, 2009). To improve stratigraphical correlations further, geochemical proxy records can be of good use. A very suitable chemostratigraphical

* In: Jagt, J.W.M., Jagt-Yazykova, E.A. \& Schins, W.J.H. (eds): A tribute to the late Felder brothers - pioneers of Limburg geology and prehistoric archaeology. 


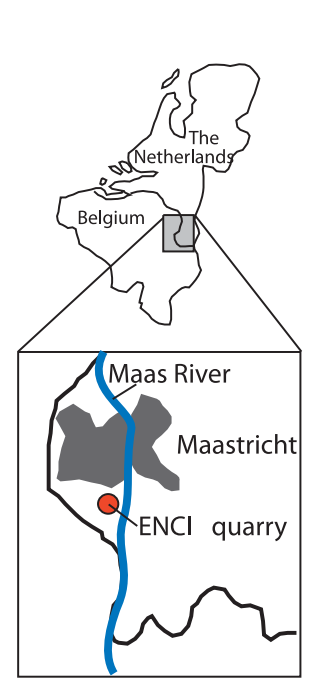

a.

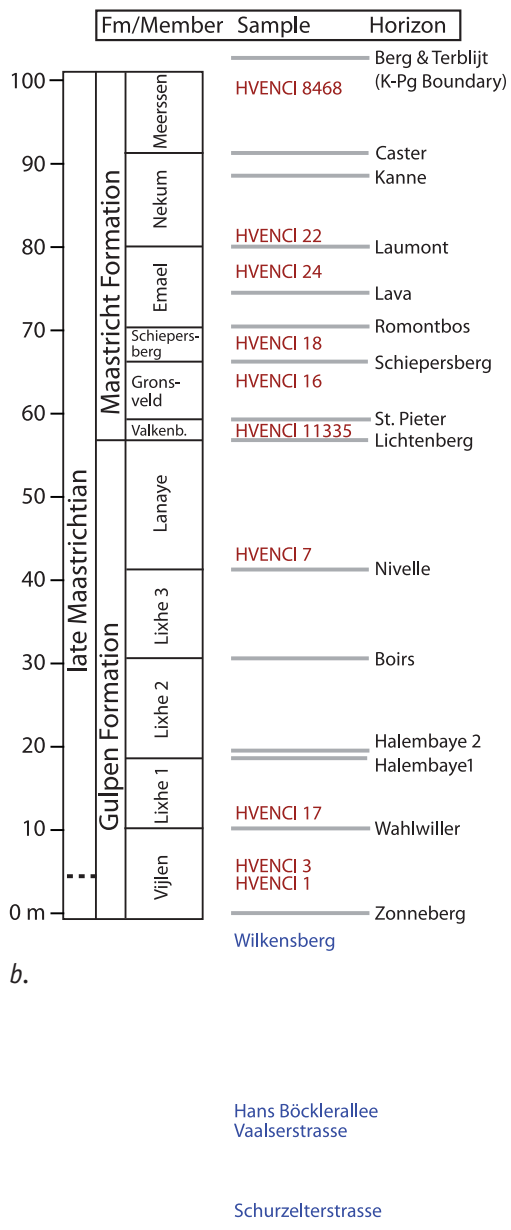

c.

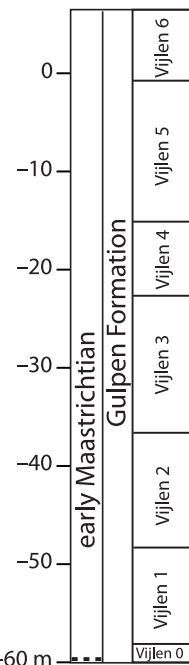

Fig. 1a. Schematic map showing the position of the Maastrichtian stratotype at the ENCI-HeidelbergCement Group quarry, south of Maastricht; b. Composite stratigraphical log of the ENCI-HeidelbergCement Group quarry sequence, with the metre scale set at 0 at the Zonneberg Horizon, the present-day lowest level exposed at the quarry. The stratigraphic context of belemnite samples analysed is indicated; $c$. for the section below the Zonneberg Horizon, covering Vijlen Member intervals 0-5, metre levels are adopted as measured in the biostratigraphically well-constrained Mamelis sequence. Note: belemnites studied from the Vijlen Member interval originate from other outcrops and are biostratigraphically placed within the Mamelis key section (compare Keutgen et al., 2010).

tool in this context is the analysis of the Sr isotope $\left({ }^{87} \mathrm{Sr} /{ }^{86} \mathrm{Sr}\right)$ composition of well-preserved marine fossils. With this tool, geographically distant sequences can be compared in detail because Sr isotope evolution of ancient seawater, as recorded in carbonate fossils, is thought to have been identical for all ocean basins and seas due to the chemically conservative behaviour of dissolved strontium in ocean water (see e.g., Hess et al., 1986). An additional advantage of Sr isotope analysis of marine fossils is that this proxy is not sensitive to temperature, metabolism or other environmental fractionation processes; it exclusively records the $\mathrm{Sr}$ isotope composition of seawater. The most important concern for the proper application of Sr isotope stratigraphy is that diagenetic alteration can change the original $\mathrm{Sr}$ isotope signature of carbonate fossils. For the Maastrichtian type area this has been demonstrated in a previous $\mathrm{Sr}$ isotope study of various carbonate fossil groups (Vonhof \& Smit, 1996). Results from that study showed that only the least altered fossils from that sequence could be assumed to have retained the ${ }^{87} \mathrm{Sr} /{ }^{86} \mathrm{Sr}$ values of Maastrichtian seawater.

\section{${ }^{87} \mathrm{Sr} /{ }^{86} \mathrm{Sr}$ variation in the Maastrichtian}

A substantial number of Sr isotope stratigraphical (SIS) studies have already been conducted for Late Cretaceous sequences (e.g., Hess et al., 1986; Macdougall, 1988; Martin \& Macdougall, 1991; Nelson et al., 1991; McArthur et al., 1993, 1994, 1998; McLaughlin et al., 1995; Sugarman et al., 1995; MacLeod \& Huber, 1996; Vonhof \& Smit, 1996, 1997; Barrera et al., 1997). The morethan-average interest in this time interval is to a large extent explained by the relatively long and steep rise of the marine ${ }^{87} \mathrm{Sr} /{ }^{86} \mathrm{Sr}$ curve throughout the Late Cretaceous, making it a very suitable time interval for reliable SIS dating. Amongst these studies, only a limited number offer the stratigraphical detail that allows for an evaluation of ${ }^{87} \mathrm{Sr} /{ }^{86} \mathrm{Sr}$ variation within the Maastrichtian interval. Many of these high-resolution studies in fact targeted the Cretaceous/Paleogene $(\mathrm{K} / \mathrm{Pg})$ boundary, seeking evidence for chemical changes in ocean water due to either a meteorite impact, or Deccan Trap basalt outflow (Macdougall, 1988; Meisel et al., 1995; MacLeod \& Huber, 1996; Vonhof \& Smit, 1997). While the earlier ${ }^{87} \mathrm{Sr} /{ }^{86} \mathrm{Sr}$ reference curves for the Late Cretaceous showed steadily rising oceanic ${ }^{87} \mathrm{Sr} /{ }^{86} \mathrm{Sr}$ ratios through the Maastrichtian (Hess et al., 1986; Sugarman et al., 1995), some of the subsequent, more detailed studies suggested that the Maastrichtian interval showed distinctive variation in ${ }^{87} \mathrm{Sr} /{ }^{86} \mathrm{Sr}$ values that could potentially be used as a high-resolution chemostratigraphical correlation tool (McLaughlin et al., 1995; Barrera et al., 1997; Vonhof \& Smit, 1997). However, results of these studies did not match particularly well, suggesting that diagenetic alteration may have affected the patterns observed. All studies were based on carbonate fossils that showed, to some extent, signs of diagenetic alteration, and the question whether or not the chemical preservation of foraminifera (e.g., Barrera et al., 1997; Vonhof \& Smit, 1997) was better than that of preleached nannofossil chalk (e.g., McLaughlin et al., 1995), remained difficult to answer.

In any case, it was never disputed that the Late Cretaceous SIS was most reliable when it could be based on analyses of well-preserved macrofossils, such as belemnitellid coleoids (Cephalopoda). The relatively stable low-magnesium calcite 
mineralogy of their rostra (Spaeth et al., 1971; Sælen, 1989; Niebuhr \& Joachimski, 2002), combined with the dense rostrum structure explains the relatively good chemical preservation of belemnites in sequences where most other biogenic carbonates are diagenetically altered. Although (partial) alteration of belemnites has been observed, carefully sampled rostra are generally regarded to reflect Mesozoic seawater chemistry and growth conditions better than most other fossils (Spaeth et al., 1971; Veizer \& Fritz, 1976; Sælen et al., 1996; Podlaha et al., 1998; Van de Schootbrugge et al., 2000; McArthur et al., 2001, 2004).

Rostra of belemnitellids rank amongst the best-preserved macrobiota in the Maastrichtian stratotype area as well. Therefore, we here present a new ${ }^{87} \mathrm{Sr} /{ }^{86} \mathrm{Sr}$ data set based on well-preserved belemnites from the Gulpen and Maastricht formations. This data set is meant to provide a better insight into the evolution of Maastrichtian seawater ${ }^{87} \mathrm{Sr} /{ }^{86} \mathrm{Sr}$ values at high stratigraphical resolution, unaffected by diagenetic alteration which obscured patterns observed in earlier records.

\section{Material and methods}

We took stratigraphically well-constrained belemnite samples ourselves from the ENCI-Heidelberg Cement Group quarry in recent years. With some exceptions, belemnites occur only in relatively low numbers throughout the sequence. Initially, this resulted in extensive stratigraphical gaps between successive belemnite samples. 0wing to the kind assistance of several members of the local geological society (Nederlandse Geologische Vereniging, Afdeling Limburg), we were able to increase the stratigraphical coverage of our data set considerably. Nearby outcrops in northeast Belgium and the Aachen area (Germany) provided rostra from the lower Maastrichtian interval which is not exposed at the ENCI-Heidelberg Cement Group quarry. After initial diagenetic screening, we selected belemnites from ten stratigraphic levels within the upper Maastrichtian section of that quarry, and an additional seven from various quarries covering the lower Maastrichtian interval for Sr isotope analysis.

Four of the belemnite samples presented in Table 1 were prepared by picking mm-sized fragments from crudely crushed rostra under a binocular microscope. The other belemnites were cut along the ventral fissure, in order to expose the alveolus, and prepared as $300 \mu \mathrm{m}$ thin sections. These thin sections were microsampled with a computer-controlled dentist drill (a Merchantek Micromill system), which enabled very precise drilling of those sections of belemnite which consisted of dense, transparent calcite, not intersected by cracks or visible growth lines. This procedure produced 1-2 mg of sample powder per belemnite. Of each micromilled sample, $\sim 1 \mathrm{mg}$ of powdered belemnite was processed for ${ }^{87} \mathrm{Sr} /{ }^{86} \mathrm{Sr}$ analysis. Further, a split of $\sim 20 \mu \mathrm{g}$ was analysed for $\delta^{18} 0$ and $\delta^{13} \mathrm{C}$ and another $\sim 200-300 \mu \mathrm{g}$ of sample powder was used for ICP-AES analyses. Two samples produced too little powder to analyse more than the ${ }^{87} \mathrm{Sr} /{ }^{86} \mathrm{Sr}$ ratio (Table 1 ).
Carbon and oxygen isotope ratios were analysed on a Finnigan MAT 252 mass spectrometer, equipped with a Kiel II automated carbonate extraction line. Samples were digested in concentrated orthophosphoric acid at 80 degrees Celsius. A routinely analysed carbonate standard was reproducible within $0.09 \%$ for $\delta^{18} 0$ and $0.05 \%$ for $\delta^{13} \mathrm{C}(1 \mathrm{SD})$. Both $\delta^{18} 0$ and $\delta^{13} \mathrm{C}$ data are reported relative to the Vienna-PDB (V-PDB) standard.

Trace element analyses were performed on a Varian Liberty ICP-AES after digestion of $\sim 0.2-0.5 \mathrm{mg}$ of powdered sample in a $\sim 0.1 \mathrm{~N} \mathrm{HNO}_{3}$ sample solution. Concentrations of $\mathrm{Fe}, \mathrm{Mn}, \mathrm{Mg}$ and $\mathrm{Sr}$ are reported in parts per million ( $\mathrm{ppm}$ ). Most samples were well below the relatively conservative ICP-AES detection limits of $\sim 40 \mathrm{ppm}$ for both $\mathrm{Mn}$ and Fe in calcite (equivalent to $\sim 4 \mathrm{ppb}$ in solution). $\mathrm{Sr}$ and $\mathrm{Mg}$ concentrations were always well above detection limits. An internal lab standard, which is routinely incorporated within sample runs, indicates a longer term reproducibility (1SD) of $2 \%$ for $\mathrm{Sr}$ and $\mathrm{Mg}$ and $5 \%$ for Fe and $\mathrm{Mn}$.

For ${ }^{87} \mathrm{Sr} /{ }^{86} \mathrm{Sr}$ analyses, $\sim 1 \mathrm{mg}$ of powdered belemnite was dissolved and Sr was separated with 'Elchrom Sr spec' ion exchange resin. ${ }^{87} \mathrm{Sr} /{ }^{86} \mathrm{Sr}$ ratios were analysed on a Finnigan MAT 261 or MAT 262 mass spectrometer, running a triple jump routine, applying exponential fractionation correction, and normalising to ${ }^{86} \mathrm{Sr} /{ }^{88} \mathrm{Sr}=0.1194$. All ${ }^{87} \mathrm{Sr} /{ }^{86} \mathrm{Sr}$ data are reported relative to a value of 0.710248 for the routinely analysed NBS 987 standard. Long term NBS 987 reproducibility was better than 0.000015 (2 SD) on both machines used. Sr blanks were $<0.01 \%$ of the total Sr concentration in the samples. Data from previous publications used here for comparison are recalculated to match the same value for the NBS 987 standard.

The geological timescale used in the present paper is that of Gradstein et al. (2004).

\section{Results and discussion}

\section{Litho- and biostratigraphy of the sequence studied}

The ENCI-HeidelbergCement Group quarry sequence consists mainly of shallow-water carbonate sediments of late to latest Maastrichtian age. Some hardgrounds and condensation levels in the top half of the quarry sequence suggest that small hiatuses are present, but the general stratigraphical framework of the quarry suggests these hiatuses to be of short duration (Schiøler et al., 1997). Since it comprises the stratotype of the Maastrichtian Stage, its lithostratigraphy has been worked out in considerable detail (W.M. Felder, 1995; see Fig. 1). The principal lithostratigraphical markers are regionally correlatable horizons which separate the formal lithostratigraphical units (members) within the Gulpen and Maastricht formations in the area. A commonly used stratigraphical sequence, including the names of the most important horizons, is presented here in Fig. 1, together with a metre scale and indication of the provenance level of belemnite samples analysed. The metre scale is set at zero at the Zonneberg Horizon, which was the lowest recognisable 
Table 1. Summary of geochemical data of belemnites from the Maastricht record. Sr isotope data are reported relative to a value of 0.710245 for the NBS 987 standard. The '<20' notation for many of the Fe and Mn concentration data indicate values lower than the 20 ppm detection limit applied in the present study; $n a=$ not analysed, usually due to insufficient sample powder availability. Sample localities for the Vijlen Member intervals are discussed in more detail in Keutgen et al. (2010).

\begin{tabular}{|c|c|c|c|c|c|c|c|c|c|c|c|}
\hline Identifier & Locality & $\begin{array}{l}\text { Sampling } \\
\text { technique }\end{array}$ & $\begin{array}{l}\text { Strat. level } \\
\text { (m) }\end{array}$ & ${ }^{87} \mathrm{Sr} /{ }^{86} \mathrm{Sr}$ & $\begin{array}{l}\text { Anal. error } \\
\text { (2se) }\end{array}$ & $\begin{array}{l}\delta^{13} \mathrm{C} \\
\text { (VPDB) }\end{array}$ & $\begin{array}{l}\delta^{18} 0 \\
(\mathrm{VPDB})\end{array}$ & $\begin{array}{l}\text { Fe } \\
(\mathrm{ppm})\end{array}$ & $\begin{array}{l}\mathrm{Mn} \\
(\mathrm{ppm})\end{array}$ & $\begin{array}{l}\text { Sr } \\
(\mathrm{ppm})\end{array}$ & $\begin{array}{l}\mathrm{Mg} \\
(\mathrm{ppm})\end{array}$ \\
\hline Beutenaken 1 & Teuven & micromilled & -65 & 0.707666 & 0.000007 & 2.10 & 0.13 & $<20$ & $<20$ & 1491 & 1994 \\
\hline Beutenaken 2 & Pesaken & micromilled & -60 & 0.707699 & 0.000006 & 2.70 & 0.32 & 141 & $<20$ & 1666 & 2386 \\
\hline Vijlen basis & Slenaken & micromilled & -58 & 0.707744 & 0.000006 & 0.99 & 0.82 & $<20$ & $<20$ & 1487 & 2058 \\
\hline Vijlen 4 & Vaalserstrasse & micromilled & -22 & 0.707760 & 0.000006 & 2.23 & 0.94 & $<20$ & $<20$ & 1413 & 2155 \\
\hline Vijlen 3 & Schurzelterstrasse & micromilled & -30 & 0.707785 & 0.000009 & 1.81 & 0.78 & $<20$ & $<20$ & 1480 & 2170 \\
\hline Vijlen 4 & Hans Böcklerallee & micromilled & -20 & 0.707763 & 0.000006 & 1.28 & 0.99 & $<20$ & $<20$ & 1385 & 1977 \\
\hline Vijlen 6 & Wilkensberg & micromilled & -3 & 0.707754 & 0.000005 & 1.94 & 0.97 & $<20$ & $<20$ & 1496 & 2143 \\
\hline 99HVENCI 01 & ENCI quarry & micromilled & 1.5 & 0.707778 & 0.000006 & na & na & na & na & na & na \\
\hline 99HVENCI 02 & ENCI quarry & micromilled & 2 & 0.707780 & 0.000006 & 1.30 & 0.24 & $<20$ & $<20$ & 1468 & 5521 \\
\hline ENCI 11388 & ENCI quarry & bulk & 2 & 0.707805 & 0.000006 & 1.33 & 0.40 & 35 & $<20$ & 1635 & 3120 \\
\hline 99HVENCI 04 & ENCI quarry & micromilled & 4 & 0.707784 & 0.000006 & 2.13 & -0.18 & $<20$ & $<20$ & 1445 & 3563 \\
\hline 99HVENCI 12 & ENCI quarry & micromilled & 18.5 & 0.707814 & 0.000006 & 1.47 & -0.41 & 53 & $<20$ & 1451 & 2637 \\
\hline 99HVENCI 07 & ENCI quarry & micromilled & 45 & 0.707822 & 0.000006 & 1.47 & -0.44 & $<20$ & $<20$ & 1765 & 3433 \\
\hline ENCI 11282 & ENCI quarry & bulk & 56 & 0.707826 & 0.000005 & 1.25 & -0.36 & $<20$ & $<20$ & 1192 & na \\
\hline ENCI 11275 & ENCI quarry & bulk & 66 & 0.707826 & 0.000005 & 1.01 & 0.35 & $<20$ & $<20$ & 1088 & na \\
\hline 99HVENCI 18 & ENCI quarry & micromilled & 70 & 0.707814 & 0.000007 & 1.29 & 1.01 & $<20$ & $<20$ & 2113 & 4691 \\
\hline 99HVENCI 22 & ENCI quarry & micromilled & 80 & 0.707820 & 0.000005 & 0.55 & 0.43 & $<20$ & $<20$ & 1553 & 2930 \\
\hline ENCI Caster & ENCI quarry & micromilled & 91 & 0.707826 & 0.000006 & 1.62 & 0.44 & $<20$ & $<20$ & 1505 & 2906 \\
\hline 99HVENCI 8290 & ENCI quarry & micromilled & 98 & 0.707828 & 0.000005 & na & na & na & na & na & na \\
\hline 99HVENCI 8469 & ENCI quarry & micromilled & 98 & 0.707837 & 0.000005 & 0.33 & 0.31 & $<20$ & $<20$ & 1662 & 1140 \\
\hline ENCI 8468 & ENCI quarry & bulk & 98 & 0.707851 & 0.000006 & 0.36 & 0.17 & $<20$ & $<20$ & 1385 & 953 \\
\hline
\end{tabular}

marker bed at the quarry at the time of sample collecting. This particular horizon is situated within the upper portion of the Vijlen Member (Gulpen Formation), close to the lower/upper Maastrichtian boundary (Jagt, 2005, 2010; Keutgen et al., 2010). The top of the Maastrichtian sequence at the ENCI-Heidelberg Cement Group quarry has been shown to be truncated only a few metres (c. 2-3 m) below the $\mathrm{K} / \mathrm{Pg}$ boundary, which is accessible at the nearby Ankerpoort-Curfs quarry, now defunct, and at the Geulhemmerberg underground galleries (Brinkhuis \& Smit, 1996; Smit \& Brinkhuis, 1996). Thus, the ENCI-HeidelbergCement Group quarry sequence spans almost the entire late Maastrichtian time interval. The lower Maastrichtian and uppermost Campanian are represented by samples from the Vijlen and Beutenaken members (Gulpen Formation), as exposed at various outcrops in northeast Belgium and the Aachen area (Germany; see Table 1). For more detailed discussions of macrofossil biozonations of the Upper Cretaceous in the area reference is made to Schiøler et al. (1997), Jagt $(2005,2010)$ and Keutgen et al. (2010).

\section{Diagenetic screening}

For a meaningful revision of the SIS record of the Maastrichtian stratotype, thorough sample screening was required to minimise contamination by diagenetically altered material in our samples.
As noted by previous authors (e.g., Veizer \& Fritz, 1976; Sælen, 1989; Sælen et al., 1996; Podlaha et al., 1998; Niebuhr \& Joachimski, 2002; Van de Schootbrugge et al., 2005), thin sections of belemnite rostra investigated under a cathodoluminescence microscope show a characteristic distribution pattern of altered and unaltered areas. Altered areas are commonly the exterior portions of the shells, bored and cracked zones, the calcite along the apical line and zones along some (but not all) visible growth lines. Increased diagenetic alteration often leads to increased Fe and Mn concentrations in belemnite calcite, which is the reason why Fe and Mn concentrations of belemnite calcite are commonly used as a proxy for diagenetic alteration (Veizer \& Fritz, 1976; Podlaha et al., 1998; Van de Schootbrugge, 2000, 2005).

To avoid these potentially altered zones in the belemnites, we carefully microsampled optically homogeneous parts of thin sections of belemnite rostra, away from visible growth lines, the apical line and the outer surface of the belemnite. Fe and Mn concentrations of a split of the resultant sample powders were analysed to check if this approach indeed produced diagenetically unaltered sample powders.

The importance of careful diagenetic screening is probably best illustrated by the results of detailed trace element and stable isotope analyses of the rostrum of a diagenetically altered 
belemnite from the ENCI-Heidelberg Cement Group quarry (Fig. 2). A thin section of this belemnite was microsampled parallel to the growth lines in several subintervals from the apical line towards the more transparent portions of the rostrum. The sample subintervals chosen can in principle be stacked on top of each other to form a continuous ontogenetic growth sequence. The geochemical profile through this ontogenetic sequence shows distinct 'sawtooth' cycles in Fe and Mn, and a more detailed inspection of this pattern shows that elevated Fe and $\mathrm{Mn}$ values consistently occur in samples that are closest to the apical line. This indicates a significant diagenetic overprint on geochemical composition of the calcite around the apical line. The fact that $\delta^{18} 0$ (and $\delta^{13} \mathrm{C}$ ) values co-vary with Fe and $\mathrm{Mn}$ concentrations shows that isotope values are also influenced by diagenesis. An increasing degree of diagenesis, as indicated by increased $\mathrm{Fe}$ and $\mathrm{Mn}$ concentrations, thus corresponds with lower $\delta^{18} 0$ and $\delta^{13} \mathrm{C}$ values. Earlier studies of diagenetic carbonates in this area suggested that meteoric diagenesis formed a significant portion of the diagenetic calcites in the upper Maastrichtian sequence (Elorza et al., 1996; Vonhof \& Smit, 1996; Kenter et al., 1997). The observed diagenetic trend towards lower $\delta^{18} 0$ and $\delta^{13} \mathrm{C}$ values is indeed a commonly observed pattern in meteoric diagenesis. The existence of a regional karst horizon truncating the top few metres of the Maastrichtian sequence at the ENCI-Heidelberg Cement Group quarry further testifies to the importance of meteoric diagenesis in the Maastrichtian interval.

The zones in the rostra that we carefully selected with our sampling method are typically not those of diagenetic alteration discussed in the example above. Our success in avoiding diagenetically altered zones is confirmed by the generally low concentrations of $\mathrm{Fe}$ and $\mathrm{Mn}$ for the samples that we picked for Sr isotope analysis (Table 1). Therefore, we assume all belemnites analysed to have retained their original marine ${ }^{87} \mathrm{Sr} /{ }^{86} \mathrm{Sr}$ composition, with the possible exception of specimen 'Beutenaken 2', which reveals a distinctly elevated Fe concentration.

\section{${ }^{87} \mathrm{Sr} /{ }^{86} \mathrm{Sr}$ data from the Maastrichtian stratotype area}

The results of all belemnite ${ }^{87} \mathrm{Sr} /{ }^{86} \mathrm{Sr}$ analyses from the Maastrichtian stratotype area are shown in Fig. 3, in relation to data published by Vonhof \& Smit (1996). The belemnite data form a well-constrained curve which remains at a plateau around a value of 0.707820 for most of the ENCI-Heidelberg Cement Group quarry stratigraphy studied. Only in the lowest interval of the current ENCI stratigraphical log do ${ }^{87} \mathrm{Sr} /{ }^{86} \mathrm{Sr}$ values drop significantly below that plateau. In the lower stratigraphical interval, as recorded in the belemnites collected at quarries and outcrops in Belgium and Germany, consistently lower ${ }^{87} \mathrm{Sr} /{ }^{86} \mathrm{Sr}$ values than in the ENCI-HeidelbergCement Group sequence are noted.

The earlier ${ }^{87} \mathrm{Sr} /{ }^{86} \mathrm{Sr}$ data from the quarry supplied by Vonhof \& Smit (1996) shows considerably more variation and consistently plot above the curve defined by the belemnite samples. This confirms the conclusions drawn by Vonhof \& Smit (1996) that diagenetic alteration shifted the ${ }^{87} \mathrm{Sr} /{ }^{86} \mathrm{Sr}$ ratio of many of the carbonate fossils in the ENCI-Heidelberg Cement Group sequence to higher values. Such a shift is likely due to meteoric diagenesis, bringing radiogenic Sr from the

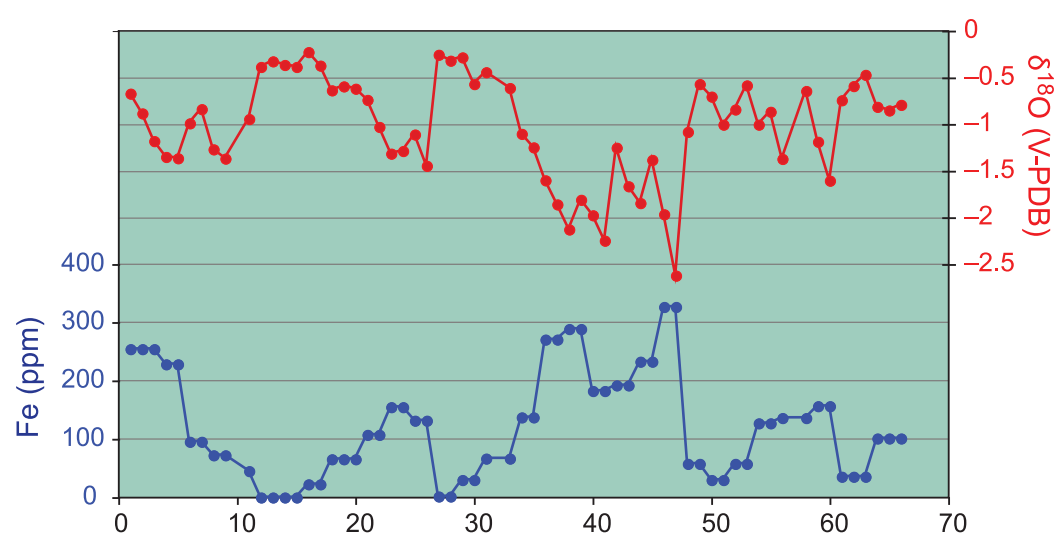

a.

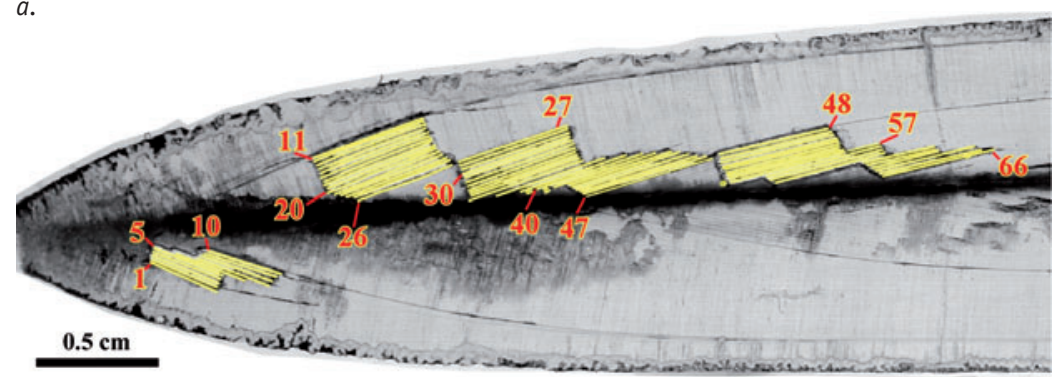

b.
Fig. 2a. Graph illustrating a sclerochronologic record of oxygen isotope and Fe concentration data of belemnite sample HVENCI-17 (see Fig. 1b). Conspicuous antiphase behaviour of $\mathrm{Fe}$ concentration and $\delta^{18} \mathrm{O}$ values of belemnite calcite indicates diagenetic alteration to have controlled $\delta^{18} 0$ variation; $b$. photomicrograph of a thin section of belemnite sample HVENCI-17, showing the microsample traces made to produce the record in Fig. $2 a$. A closer inspection of Fig. $2 a$ and $b$ reveals that high $\mathrm{Fe}$ concentrations (and low $\delta^{18} 0$ values) consistently occur in samples close to the apical line (dark horizontal line along the central axis of the belemnite in Fig. 2b) where diagenetic fluids were able to penetrate the rostrum. 
Fig. 3. Graph showing all Sr isotope data of belemnites analysed for this study (in red) compared to previously published Sr isotope analyses of other fossils from the ENCI-HeidelbergCement Group and Ankerpoort-Curfs quarries, Geulhem (in blue; see Vonhof \& Smit, 1996). Data points from the Vonhof \& Smit (1996) study show a significantly higher scatter and raised ${ }^{87} \mathrm{Sr} /{ }^{86} \mathrm{Sr}$ values than those of the belemnites, which we interpret as the result of diagenetic alteration in the former data set. Belemnite ${ }^{87} \mathrm{Sr} /{ }^{86} \mathrm{Sr}$ data define two periods of relatively stable ${ }^{87} \mathrm{Sr} /{ }^{86} \mathrm{Sr}$ values; these plateaus are connected by a relatively rapid transition, indicated by a yellow vertical bar. In the belemnite data, open circles represent the four samples that were prepared from discrete belemnite fragments, while closed circles represent micromilled belemnite rostra.

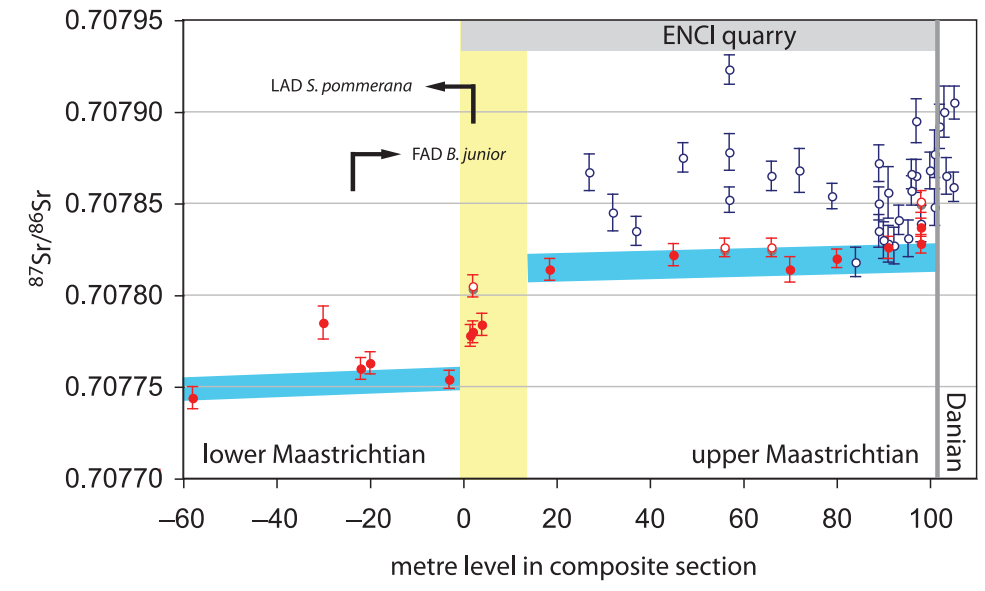

overlying Cenozoic strata down into the Maastrichtian sequence. The belemnites used in the present study define a curve through the lowest values of the combined data set, which supports their excellent chemical preservation.

\section{Comparison to other Late Cretaceous SIS records}

The Sr isotope curve of the belemnites from the ENCI-Heidelberg Cement Group quarry can be correlated, in reasonable stratigraphical detail, with several other detailed late Maastrichtian ${ }^{87} \mathrm{Sr} /{ }^{86} \mathrm{Sr}$ records from 0DP site 690 (Barrera et al., 1997), El Kef (Vonhof \& Smit, 1997) and Hemmoor (McLaughlin et al., 1995; Barrera et al., 1997; Vonhof \& Smit, 1997).

\section{1 - Hemmoor}

The former Hemmoor section in northern Germany compares well in biostratigraphical detail with the Maastricht record, because both yield a Boreal fauna. Numerous chalk ${ }^{87} \mathrm{Sr} /{ }^{86} \mathrm{Sr}$ analyses reveal a pattern that steps up from values of 0.707760 at the base of the section to a plateau at 0.70780 (McLaughlin et al., 1995) (see Fig. 4). Notably, the Hemmoor record does not span the complete upper Maastrichtian. More than $100 \mathrm{~m}$ of sediment have been eroded from the top of the section (Niebuhr,

2006), so that comparison with the top part of the Maastricht record is not possible. In the lower portion of the plateau at $+5 \mathrm{~m}$ Belemnitella junior, the belemnite marker for the base of the upper Maastrichtian in the Boreal Realm, first appears (Schulz et al., 1984; 0gg et al., 2008). The similarity of the step pattern near the lower/upper Maastrichtian boundary at both localities suggests that this ${ }^{87} \mathrm{Sr} /{ }^{86} \mathrm{Sr}$ pattern is a palaeoceanographical phenomenon recorded in both sections. However, if that is the case, then the SIS fit of the sections reveals some inconsistencies in the biostratigraphical correlation between Hemmoor and Maastricht. Particularly the first appearance datum (FAD) of Belemnitella junior, the coleoid index for the base of the upper Maastrichtian in the Boreal Realm, occurs at $+5 \mathrm{~m}$ in the Hemmoor section (Schulz et al., 1984; see Fig. 4 here) and at approximately $-22 \mathrm{~m}$ in the Maastricht section (Keutgen et al., 2010; see Fig. 3 here). At Hemmoor, the $+5 \mathrm{~m}$ level corresponds to the higher ${ }^{87} \mathrm{Sr} /{ }^{86} \mathrm{Sr}$ plateau (Fig. 4), while the $-22 \mathrm{~m}$ level for Maastricht is on the lower ${ }^{87} \mathrm{Sr} /{ }^{86} \mathrm{Sr}$ plateau (Fig. 3). This either means that the FAD of $B$. junior as determined in these two sections is diachronous, or that the SIS correlation is incorrect. To shed more light on this question we have also plotted existing foraminiferal biostratigraphical zonations for both sections. Of particular relevance in this context is the last appearance datum (LAD) of Stensioeina pommerana, which
Fig. 4. Graph showing ${ }^{87} \mathrm{Sr} /{ }^{86} \mathrm{Sr}$ values of chalk from the Hemmoor section (northern Germany; McLaughlin et al., 1995). Although the top part of the upper Maastrichtian is not present in this section, data available suggest a distinct ${ }^{87} \mathrm{Sr} /{ }^{86} \mathrm{Sr}$ transition to occur between $0 \mathrm{~m}$ and $-20 \mathrm{~m}$ from a lower to a higher ${ }^{87} \mathrm{Sr} /{ }^{86} \mathrm{Sr}$ plateau. The FAD of Belemnitella junior and the LAD of Stensioeina pommerana are indicated. See text for discussion of the biostratigraphical data; we correlate the ${ }^{87} \mathrm{Sr} /{ }^{86} \mathrm{Sr}$ step pattern, indicated by a yellow vertical bar, to the step in ${ }^{87} \mathrm{Sr} /{ }^{86} \mathrm{Sr}$ values visible in the Maastricht record (see Fig. 3).

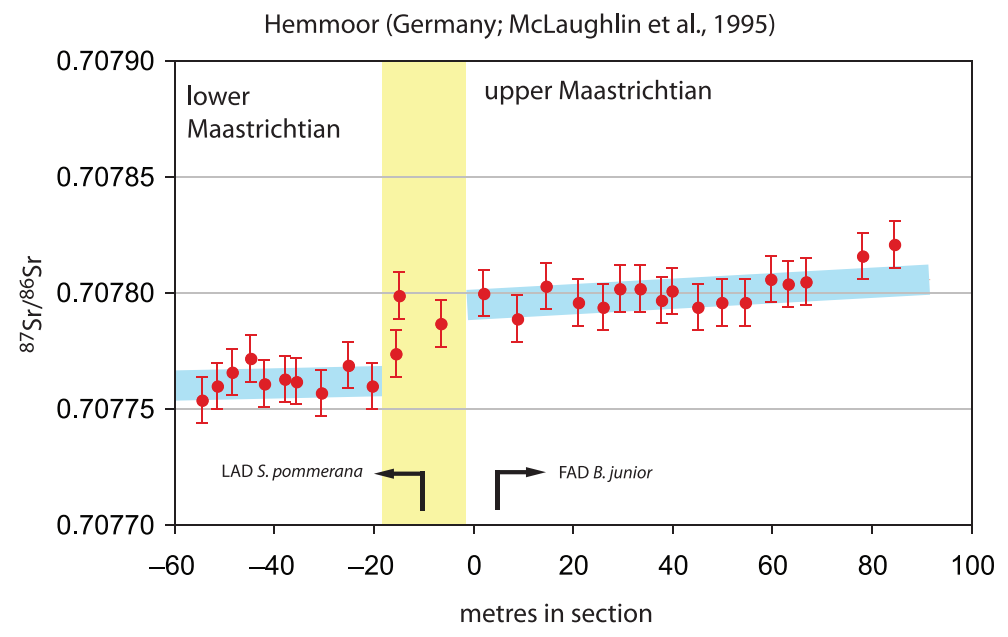


ODP site 690 (Maud Rise Antarctica; Barrera et al, 1997)

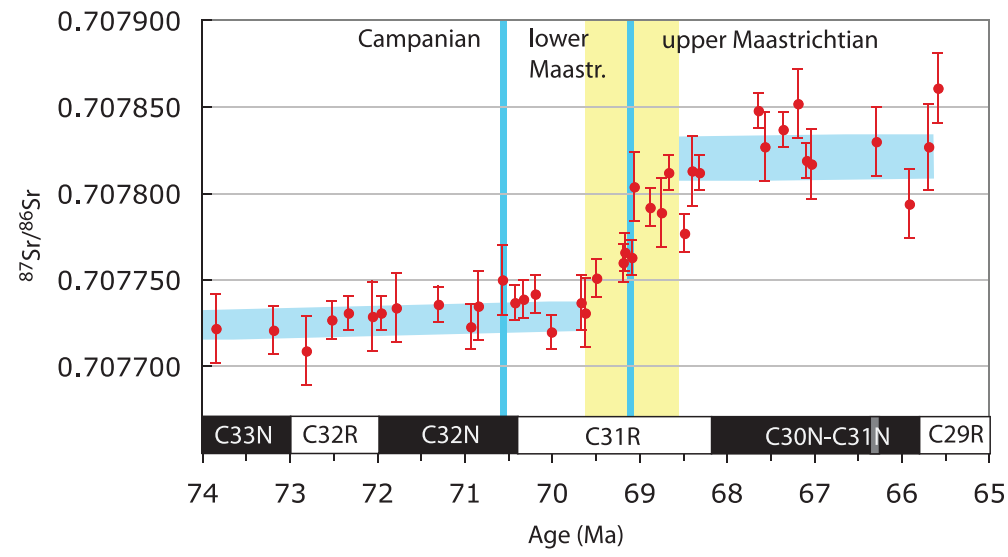

Fig. 5. Graph showing ${ }^{87} \mathrm{Sr} /{ }^{86} \mathrm{Sr}$ values of well-preserved foraminifera from ODP sites 689 and 690 (Maud Rise, Antarctica; Barrera et al., 1997). This record shows a ${ }^{87} \mathrm{Sr} /{ }^{86} \mathrm{Sr}$ pattern which is remarkably similar to that of the Maastricht record presented in Fig. 3. We have applied a simple linear age model, based on magnetostratigraphical data for the ODP sites 689 and 690 (Hamilton, 1990), to place the ${ }^{87} \mathrm{Sr} /{ }^{86} \mathrm{Sr}$ record in an absolute-age framework. This age model shows that the relatively rapid transition towards the upper Maastrichtian ${ }^{87} \mathrm{Sr} /{ }^{86} \mathrm{Sr}$ plateau occurs within magnetochron C31R, which spans the lower/upper Maastrichtian boundary. occurs at $\sim 4 \mathrm{~m}$ above the Zonneberg Horizon (Jagt, 2010) at the ENCI-Heidelberg Cement Group quarry, which is $\sim 25 \mathrm{~m}$ above the FAD of $B$. junior in the Maastricht sequence (Fig. 3), and near the top of the cimbrica Zone at $15 \mathrm{~m}$ below the FAD of $B$. junior in the Hemmoor section (Hofker, 1961; Weiss, 1999; Jagt 2010). If we take the LAD of Stensioeina pommerana to represent the lower/upper Maastrichtian boundary, as suggested by Jagt (2010), then the Sr isotope profiles of the two sections fit very well, with the boundary precisely in the transition zone between the two plateaus (yellow vertical bars in Figs 3,4). While it is beyond the scope of the present paper to review existing biostratigraphical zonations, our data do suggest that the FAD of Belemnitella junior may be diachronous between these two sections.

\section{2 - ODP site 690}

Stratigraphically more complete than Hemmoor is the Maastrichtian interval of the South Atlantic 0DP sites 689 and 690, for which a good magnetostratigraphical framework is available (Hamilton, 1990). Well-preserved foraminifera from these sites were analysed by Barrera et al. (1997). Their data support the existence of a ${ }^{87} \mathrm{Sr} /{ }^{86} \mathrm{Sr}$ plateau for the late Maastrichtian, and furthermore indicate it to be preceded by another plateau, at lower ${ }^{87} \mathrm{Sr} /{ }^{86} \mathrm{Sr}$ values which spans part of the Campanian and the lower Maastrichtian (Fig. 5).

The ODP 690 magnetostratigraphical framework correlates the inflection points that mark the transition from the lower to the higher ${ }^{87} \mathrm{Sr} /{ }^{86} \mathrm{Sr}$ plateau in ODP core 690 to magnetochron C31R. This means that this ${ }^{87} \mathrm{Sr} /{ }^{86} \mathrm{Sr}$ transition indeed spans the lower/upper Maastrichtian boundary, placed at 69.2 Ma. Thus, the upper Maastrichtian ${ }^{87} \mathrm{Sr} /{ }^{86} \mathrm{Sr}$ plateau starts 3-3.5 myr prior to the $\mathrm{K} / \mathrm{Pg}$ boundary. The Campanian/Maastrichtian boundary at $\sim 70.6 \mathrm{Ma}$ is situated within the top part of magnetochron $\mathrm{C} 32 \mathrm{~N}$, somewhere in the lower ${ }^{87} \mathrm{Sr} /{ }^{86} \mathrm{Sr}$ plateau in ODP 690 (Fig. 5). Since ${ }^{87} \mathrm{Sr} /{ }^{86} \mathrm{Sr}$ values show no variation in that interval, they are of no direct help for a more precise identification of the Campanian/Maastrichtian boundary in the sequences studied.
3 - El Kef

A similar, albeit less well-defined, late Maastrichtian ${ }^{87} \mathrm{Sr} /{ }^{86} \mathrm{Sr}$ pattern is seen in the Bidart (southeast France) and El Kef (Tunisia) sections (Vonhof \& Smit, 1996). High-resolution variation in the upper Maastrichtian portion of the Bidart and El Kef records was originally interpreted as rapid seawater ${ }^{87} \mathrm{Sr} /{ }^{86} \mathrm{Sr}$ variation, driven by Deccan Trap volcanism (Vonhof \& Smit, 1997). However, with the present ENCI belemnite ${ }^{87} \mathrm{Sr} /{ }^{86} \mathrm{Sr}$ in hand, it now seems more feasible to interpret these highresolution deviations from plateau values in Bidart and El Kef to be due to subtle changes in diagenetic overprint on the foraminifera analysed. Nevertheless, the general existence of a ${ }^{87} \mathrm{Sr} /{ }^{86} \mathrm{Sr}$ plateau for the late Maastrichtian remains clear, both at Bidart and El Kef. Notably, the data set published by Vonhof \& Smit (1997) did not span the complete upper Maastrichtian. In the Bidart data set, a fault gap at 1.5 myr below the $\mathrm{K} / \mathrm{Pg}$ boundary, has removed a significant part of the stratigraphy at the onset of the late Maastrichtian ${ }^{87} \mathrm{Sr} /{ }^{86} \mathrm{Sr}$ plateau, precluding precise stratigraphic correlation of the Bidart and Maastricht ${ }^{87} \mathrm{Sr} /{ }^{86} \mathrm{Sr}$ records. The El Kef data presented in the same paper initially did not extend down into the lower Maastrichtian. In Fig. 6 we present a revised El Kef data set, into which several new ${ }^{87} \mathrm{Sr} /{ }^{86} \mathrm{Sr}$ analyses of lower Maastrichtian strata from that same sequence have been incorporated. In this revised record, a lower Maastrichtian ${ }^{87} \mathrm{Sr} /{ }^{86} \mathrm{Sr}$ plateau, comparable to the one at Maastricht and ODP site 690 becomes apparent, with a rapid transition to the upper Maastrichtian plateau around $120 \mathrm{~m}$ in the section (Fig. 6). The biostratigraphically defined lower/ upper Maastrichtian boundary, as represented by the FAD of Racemiguembelina fructicosa Nederbragt, 1991, lies at $115 \mathrm{~m}$ in the transition zone between the two Sr-isotope plateaus.

\section{Updated Maastrichtian SIS pattern}

This new compilation of high-resolution data for the upper Maastrichtian interval suggests that the Maastrichtian interval comprises two periods of relatively stable seawater ${ }^{87} \mathrm{Sr} /{ }^{86} \mathrm{Sr}$ values, connected by a stepped shift to higher values around 
El Kef (Tunisia; Vonhof and Smit, 1997)

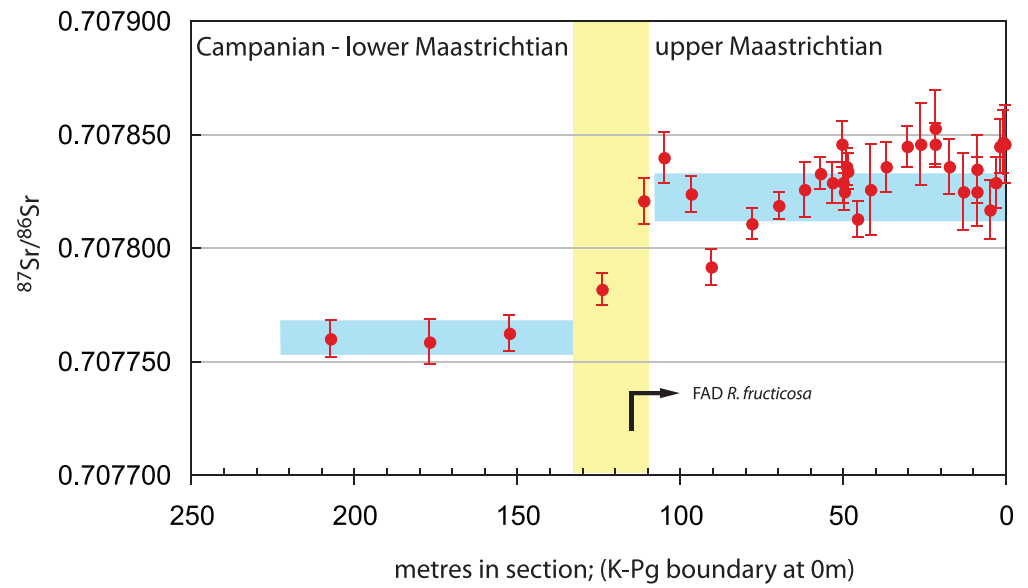

Fig. 6. Graph showing ${ }^{87} \mathrm{Sr} /{ }^{86} \mathrm{Sr}$ values of foraminifera from the El Kef section (Tunisia; see Vonhof \& Smit, 1997) with additional samples analysed to cover the lower Maastrichtian interval. The resultant pattern is interpreted to show a rapid transition from a plateau, at a value of $\sim 0.70776$, during the lower Maastrichtian interval, to an upper Maastrichtian plateau at an average value of $\sim 0.70783$. Biostratigraphical zonations (Nederbragt, 1991) indicate the ${ }^{87} \mathrm{Sr} /{ }^{86} \mathrm{Sr}$ transition (indicated by a yellow bar) to occur at the lower/upper Maastrichtian boundary (FAD of the planktonic foraminifer Racemiguembelina fructicosa at $115 \mathrm{~m}$ in section).

the lower/upper Maastrichtian boundary. This typical inflection pattern in the ${ }^{87} \mathrm{Sr} /{ }^{86} \mathrm{Sr}$ curve, linked to magnetochron $\mathrm{C} 31 \mathrm{R}$, is as a valuable chronostratigraphical marker within the Maastrichtian, with which existing biostratigraphical correlations can be compared whenever magnetostratigraphical data are not available. This inflection pattern is currently not resolved in commonly used SIS calibration curves like the one by McArthur \& Howarth (2004). We believe this to be caused by the fact that those authors based their Maastrichtian data set on two selected records, DSDP site 525 (Sugarman et al., 1995) and site 463 (Barrera et al., 1997). Of these, site 525 covers the late Maastrichtian at relatively low sampling resolution. The stratigraphically lower part of the pattern we observe in the records presented here corresponds reasonably well with the compilation by McArthur \& Howarth (2004). In contrast, a relatively poor fit results for the top part of the record, where their compilation relies entirely on DSDP 525 data, which are to some degree affected by diagenetic alteration (Sugarman et al., 1995).

The ${ }^{87} \mathrm{Sr} /{ }^{86} \mathrm{Sr}$ correlation of our new Maastricht record with ODP site 690 suggests that the lower/upper Maastrichtian boundary (at 69.2 Ma) is situated within the Vijlen Member (Gulpen Formation), more or less at the base of the section currently exposed at the ENCI-Heidelberg Cement Group quarry. This section then spans a 3.7 myr time interval, representing the nearly complete upper Maastrichtian. This chemostratigraphical determination of the lower/upper Maastrichtian boundary agrees reasonably well with biostratigraphical zonations based on benthic foraminiferal assemblages (as outlined by Jagt, 2010). On the other hand, our stratigraphical model is at odds with stratigraphical zonations based on belemnite associations, which place the lower/upper Maastrichtian boundary $\sim 26 \mathrm{~m}$ lower at the base of the Vijlen Member interval 4 of the Maastrichtian stratotype area (Keutgen et al., 2010; see Fig. 1 here). As already mentioned here above, our data seem to suggest possible diachroneity in belemnite zonations of the Maastrichtian.

Samples from the Vijlen Member interval, collected from sections in northeast Belgium and the Aachen area (within an extended Maastrichtian stratotype area), group around a value of 0.70775 , likely representing the upper Campanian to lower Maastrichtian period of stable seawater ${ }^{87} \mathrm{Sr} /{ }^{86} \mathrm{Sr}$ values which can also be observed at ODP site 690 and El Kef. A further subdivision of the Campanian and early Maastrichtian time interval on the basis of ${ }^{87} \mathrm{Sr} /{ }^{86} \mathrm{Sr}$ data is not feasible due to the lack of Sr isotope variation in that interval.

The ${ }^{87} \mathrm{Sr} /{ }^{86} \mathrm{Sr}$ values of the two stratigraphically lowest belemnite samples in this study (from the localities Teuven and Pesaken) plot well below the ${ }^{87} \mathrm{Sr} /{ }^{86} \mathrm{Sr}$ values of the belemnites higher up in the Vijlen Member. These two samples come from an interval for which common reworking of belemnite rostra is suspected (Keutgen et al., 2010) and are here interpreted to be out of stratigraphical context, i.e. likely to have been reworked from underlying upper Campanian strata. It must be noted that also for the other samples from the lower Vijlen Member, falling on the lower ${ }^{87} \mathrm{Sr} /{ }^{86} \mathrm{Sr}$ plateau in the present study, it is feasible that some reworking did take place (Keutgen et al., 2010).

\section{Stable isotope variation of the belemnites studied}

Previously published oxygen isotope data of belemnites and foraminifera have often been interpreted to indicate significant global seawater temperature change or palaeoceanographical reorganisations in the Late Cretaceous (e.g., Lowenstam \& Epstein, 1954; Barrera et al., 1997; Frank \& Arthur, 1999; Huber et al., 2002; Friedrich et al., 2009). In some cases, stable isotope data were assumed to be at least partially controlled by palaeoecological (habitat) preferences of specific belemnite species (Mutterlose et al., 2010). For carbon isotopes as well, significant variation has been observed in the Upper Cretaceous stratigraphical record (Barrera et al., 1997; Frank \& Arthur, 1999; Friedrich et al., 2009), which usually is interpreted in terms of palaeoceanographical (watermass or overturning rate) changes. Although the controls on the carbon cycle in the 
Cretaceous oceans can be complex (Nederbragt et al., 2004), the temporal marine carbon isotope variation, as recorded in Late Cretaceous carbonate fossils, is often correlatable between distant sites, thus offering a robust proxy record for chemostratigraphical correlation (Frank \& Arthur, 1999; Jarvis et al., 2006; Friedrich et al., 2009).

Thus, oxygen and carbon isotope values of our belemnite data set can potentially be used to provide more detail on palaeoceanographical changes within the Maastrichtian interval. Interpretation of belemnite stable isotope data, however, is not without complications. In several earlier studies, significant stable isotope variation between belemnite rostra from the same stratigraphical level, or even within single belemnite rostra, has been observed (Spaeth et al., 1971; Niebuhr \& Joachimski, 2002; McArthur et al., 2004; Mutterlose et al., 2010). Careful data evaluation is thus required for the interpretation of belemnite stable isotope records.

For that reason, we produced two sets of stable isotope analyses. The first (Fig. 7a) was run on subsamples of the micromilled portions of belemnites for ${ }^{87} \mathrm{Sr} /{ }^{86} \mathrm{Sr}$ analyses. The second, more extensive, set of stable isotope data (Fig. $7 \mathrm{~b}$ ) concerned high-resolution sclerochronological analysis of belemnites from the same sequence, which was done in order to determine the range of stable isotope variation occurring within individual belemnite rostra. These sclerochronological series (Fig. $7 \mathrm{~b}$ ) reveal significant (>1 permille) $\delta^{18} 0$ variation within individual specimens which often exceeds the total variation between specimens reported in Fig. 7a.

Data in Fig. $7 \mathrm{~b}$ are colour coded to show the preservational state of the belemnites analysed. Pristine belemnites (in green) do not reveal elevated Fe or Mn concentrations in any of the subsamples analysed. Partially altered belemnites (in light blue) have slightly elevated Fe or Mn in some samples, usually coinciding with visible growth lines, cracks or the apical line. For these belemnites, however, no significant correlation of elevated Fe and Mn concentrations with shifts in stable isotope values is evident. One severely altered sample (HVENCI-17) has elevated Fe or Mn concentrations for most of the samples analysed (see also Fig. 2). In this belemnite, elevated Fe and Mn concentrations co-vary significantly with both oxygen and carbon isotope values, suggesting that the stable isotope ratios in this sample have diagenetically shifted to lower values. The stable isotope values of all other (pristine and partially altered) belemnite rostra overlap markedly, and are assumed to reflect the original geochemical composition of the belemnites. For these, sclerochronological stable isotope variation should consequently be interpreted to reflect intra- and interannual environmental variability during the life span of these specimens.

If such significant $\delta^{13} \mathrm{C}$ and $\delta^{18} 0$ variation commonly occurs within well-preserved belemnite specimens in our collection, then care should be taken when interpreting the stable isotope value of the selectively microsampled portions of single specimens presented in Fig. 7a to represent the average isotope value of that particular belemnite, let alone of that stratigraphical interval (Spaeth et al., 1971; Niebuhr \& Joachimski, 2002; Mutterlose et al., 2010).

We assume the $\delta^{18} 0$ data in Fig. $7 a$ to be stratigraphically representative for the following reasons; 1 . The sclerochronological intervals that were micromilled were wide enough to ensure averaging of the typically high-frequency stable isotope variation within the belemnite rostra (Fig. 8). Only very few of the rostra examined by us exhibited ontogenetic trends that are large enough to cause significant subsampling artefacts in the isotope values; 2 . stable isotope data of micromilled samples in Fig. 7a compare well with the average values of the sclerochronologically analysed rostra presented in Fig. $7 \mathrm{~b}$, and the resultant belemnite $\delta^{18} 0$ and $\delta^{13} \mathrm{C}$ records appear to define relatively well-constrained stratigraphical trends.
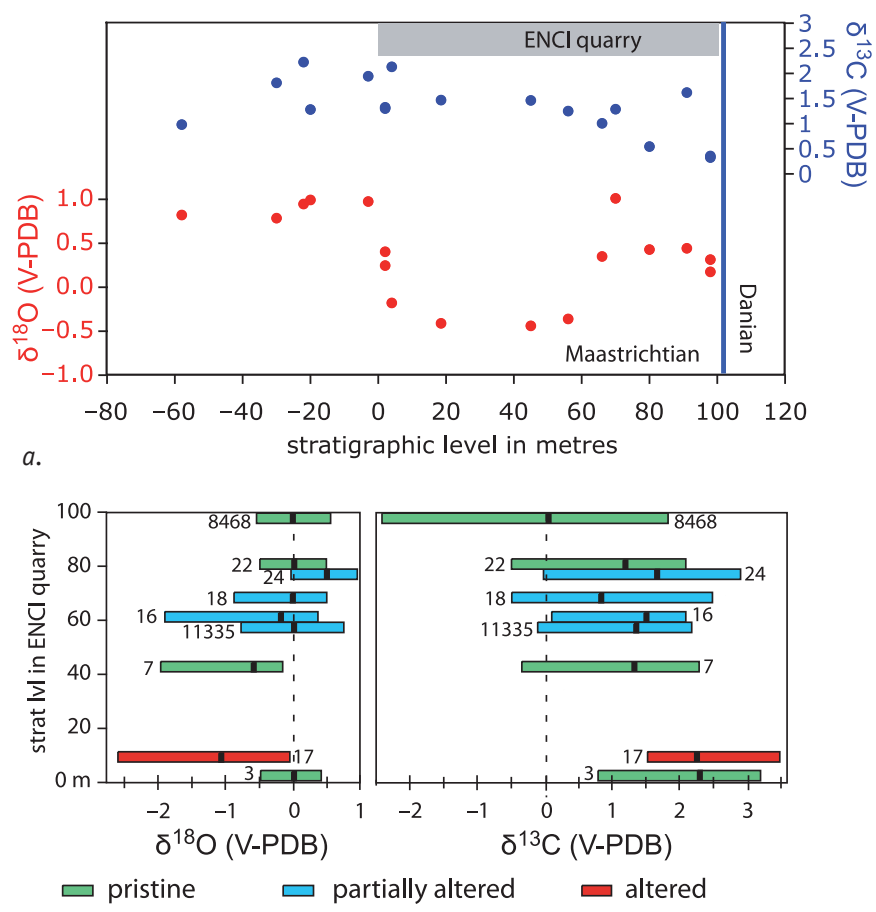

b.

Fig. 7a. Graph showing $\delta^{18} \mathrm{O}$ values (in red) and $\delta^{13} \mathrm{C}$ values of the micromilled portions of belemnites from the Maastricht sequence. $\delta^{13} \mathrm{C}$ data define a stratigraphical trend towards lower values through the complete record; $\delta^{18} 0$ values show a more complex pattern with a rapid drop of $\sim 1.5$ permille around 0 metre in the composite section, followed by an increase to higher values at $\sim 60$ metre in the section; $b$. Graphic representation of the total range of $\delta^{18} 0$ and $\delta^{13} \mathrm{C}$ values within sclerochronologically sampled belemnites at different stratigraphical levels of the ENCI-HeidelbergCement Group quarry. Colour coding of the range bars indicates the preservational state of the belemnite as reconstructed from the trace element composition of all belemnite subsamples. Average stable isotope values are indicated by a black vertical marker in the range bars. The bulk isotope values in Fig. 7 a compare relatively well to the average values of the sclerochronologically sampled belemnites in Fig. $7 \mathrm{~b}$. This suggests that stable isotope data of selectively sampled portions of the belemnites depicted in Fig. 7 a are stratigraphically representative. 
$\delta^{18} 0$ values of belemnites micromilled for ${ }^{87} \mathrm{Sr} /{ }^{86} \mathrm{Sr}$ analysis in the present study span a total range of $\sim 1.5$ permille (Fig. 7a), subdividing the record into three periods of relatively stable $\delta^{18} 0$ values, separated by rapid $\delta^{18} 0$ shifts. The most conspicuous shift is a 1.5 permille drop in $\delta^{18} 0$ at the lower/ upper Maastrichtian boundary. A similar isotope shift was observed in foraminifera from several Atlantic ODP and DSDP sites, and attributed to tectonically driven palaeoceanographical reorganisations in the Atlantic 0cean (Frank \& Arthur, 1999). It is likely that the $\delta^{18} 0$ pattern observed in the Maastricht belemnites reflect regional temperature and watermass changes in response to these larger-scale reorganisations. If the lower/upper Maastrichtian shift of $\delta^{18} 0$ values indeed relates to larger-scale tectonics, then it may not be a coincidence that it occurs during the rapid ${ }^{87} \mathrm{Sr} /{ }^{86} \mathrm{Sr}$ transition towards the upper Maastrichtian plateau. The logical interpretation here would be that tectonic reorganisations affected both the circulation pattern of the Atlantic 0cean, as well as the global seawater ${ }^{87} \mathrm{Sr} /{ }^{86} \mathrm{Sr}$ balance. The slightly smaller and more gradual shift to higher $\delta^{18} 0$ values across the transition from the Gulpen Formation to the Maastricht Formation could still relate to ongoing palaeoceanographical reorganisations in the Atlantic 0cean or, alternatively, result from a regional shift to
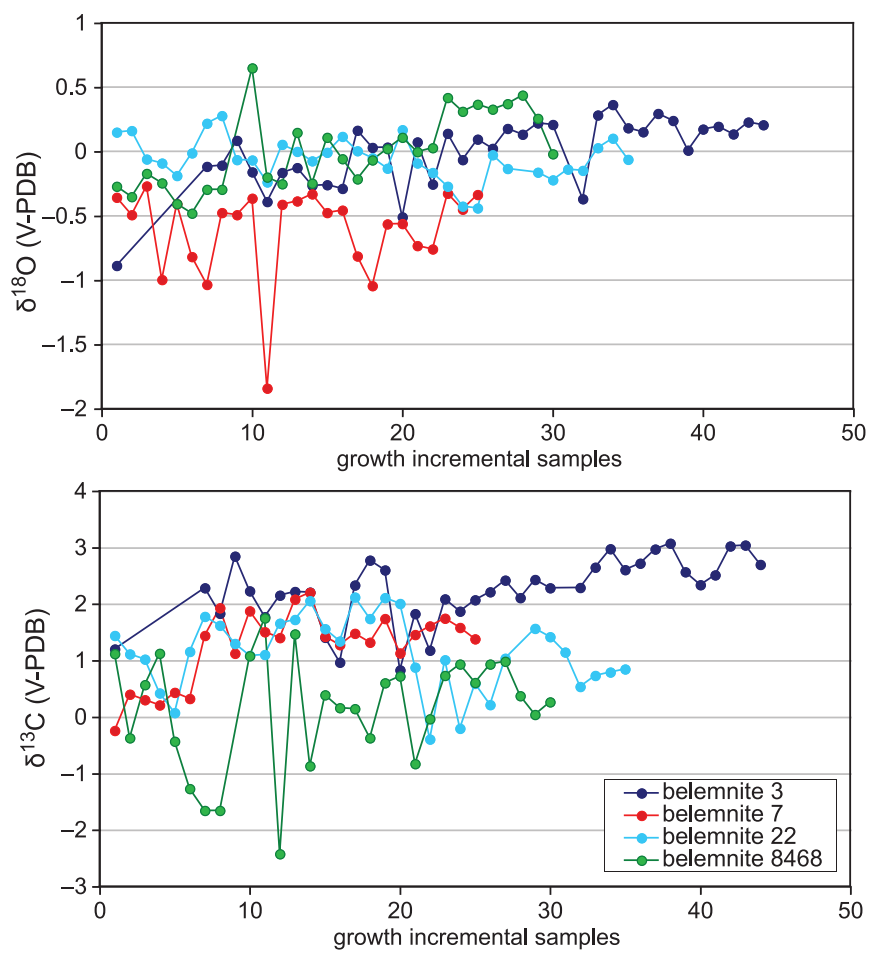

Fig. 8. Graphs showing typical growth incremental variation of $\delta^{18} 0(A)$ and $\delta^{13} C$ (B) for well-preserved belemnites from the ENCI-Heidelberg Cement Group quarry. Growth incremental sample numbers as shown on the $X$ axis generally represent 100 micrometre sample intervals. Sample numbers of the different specimens are not correlated; we have no grip on possible growth rate differences between specimens. Results indicate that isotope variation usually takes place at high frequency, and that longer trends within individual belemnites may occur, yet are not common. a more restricted marginal-marine depositional environment, as has been observed in dinoflagellate assemblages from the ENCI-Heidelberg Cement Group quarry (Schiøler et al., 1997).

The $\delta^{13} \mathrm{C}$ variation shown in our belemnite data set points at generally stable to slightly decreasing marine $\delta^{13} \mathrm{C}$ values through the Maastrichtian, which is not dissimilar to the trend visible in some, albeit not all, previously published Maastrichtian seawater $\delta^{13} \mathrm{C}$ records from ODP and DSDP cores (Frank \& Arthur, 1999). In any case, the belemnite $\delta^{13} \mathrm{C}$ data show no trends or inflection patterns that relate to patterns observed in the $\delta^{18} 0$ or ${ }^{87} \mathrm{Sr} /{ }^{86} \mathrm{Sr}$ data, suggesting that different mechanisms control the carbon isotope system.

Stable isotope patterns as observed here are not readily comparable to previously published stable isotope data of bulk carbonate samples from the Maastrichtian type area (Clauser, 1994; Felder et al., 2003). Particularly the oxygen isotope signal is difficult to reconcile between the three data sets. Both bulk carbonate $\delta^{18} 0$ data sets show lower values than the belemnite data set, which is here interpreted to be the result of a significant diagenetic overprint on bulk carbonate samples (compare Fig. 2). Stratigraphical oxygen isotope variation of bulk carbonate is thus likely to be controlled more by diagenetic processes than by palaeoceanographical variation in the Maastrichtian.

Carbon isotope values of our data set and that of Clauser (1994) and Felder et al. (2003) appear to be somewhat more consistent. All three records show comparable, relatively stable $\delta^{13} \mathrm{C}$ values through the Maastrichtian, which may suggest that the carbon isotope signal in bulk carbonate has not altered as much as the oxygen isotope signal.

\section{Conclusions}

Careful diagenetic screening suggests that belemnites from the Maastrichtian type area are only partially diagenetically altered and pristine belemnite calcite can be obtained by careful subsampling of rostra. Geochemical patterns in diagenetically altered carbonates from this sequence are consistent with meteoric diagenetic conditions which led to clear shifts in stable and radiogenic isotope values.

Stratigraphically ordered Sr isotope data of chemically wellpreserved portions of the belemnite rostra define a wellconstrained ${ }^{87} \mathrm{Sr} /{ }^{86} \mathrm{Sr}$ plateau throughout the late Maastrichtian. Late Campanian and early Maastrichtian belemnites from the same sequences define a second plateau of distinctly lower ${ }^{87} \mathrm{Sr} /{ }^{86} \mathrm{Sr}$ ratios. The inflection points in the ${ }^{87} \mathrm{Sr} /{ }^{86} \mathrm{Sr}$ curve at the transition between the two plateaus can be identified in different sequences, and thus serves as a valuable chronostratigraphical marker located at the lower/upper Maastrichtian boundary. This step-pattern is as yet not resolved in commonly used SIS databases.

0xygen isotope values of the belemnites studied here show a stratigraphical pattern that relates at least in part to previously published $\delta^{18} 0$ data for Atlantic ODP and DSDP sites in the 
Maastrichtian. We postulate that stratigraphically synchronous shifts in ${ }^{87} \mathrm{Sr} /{ }^{86} \mathrm{Sr}$ and $\delta^{18} 0$ values of the belemnites studied reflect tectonically-driven deep-water overturning changes in the Atlantic 0cean at the lower/upper Maastrichtian boundary. Carbon isotope data of the belemnites show stable to slightly decreasing values through the Maastrichtian. The $\delta^{13} \mathrm{C}$ trend is clearly not in phase with $\delta^{18} 0$ or ${ }^{87} \mathrm{Sr} /{ }^{86} \mathrm{Sr}$ variation.

\section{Acknowledgements}

Several members of the local geological society (Nederlandse Geologische Vereniging, Afdeling Limburg) were of invaluable help in this project by supplying belemnites from some key stratigraphic intervals. Technical assistance was obtained from Wynanda Koot and Bouk Lacet during thin-section preparation of the belemnites. Annemarie van Biemen and several other students at the Vrije Universiteit Amsterdam are gratefully acknowledged for assistance in the field and stable isotope analysis at Amsterdam. Lastly, we thank Birgit Niebuhr (Dresden) and Bas van de Schootbrugge (Frankfurt am Main) for pertinent comments on an earlier typescript.

\section{References}

Barrera, E., Savin, S.M., Thomas, E. \& Jones, C.E., 1997. Evidence for thermohaline-circulation reversals controlled by sea-level change in the latest Cretaceous. Geology 25: 715-718.

Brinkhuis, H. \& Smit, J., 1996. The Geulhemmerberg Cretaceous/Tertiary boundary section (Maastrichtian type area, SE Netherlands); an introduction. In: Brinkhuis, H. \& Smit, J. (eds): The Geulhemmerberg Cretaceous/Tertiary boundary section (Maastrichtian type area, SE Netherlands). Geologie en Mijnbouw 75: 101-106.

Clauser, S., 1994. Études stratigraphiques du Campanien et du Maastrichtien de l'Europe occidentale. Côte Basque, Charentes (France), Limbourg (Pays-Bas). Biochronologie, magnétostratigraphie, stratigraphie isotopique, radiochronologie comparée de domaine océanique et des régions stratotypiques. Contribution à la paléoclimatologie du Crétacé Supérieur. Documents du Bureau des Recherches Géologiques et Minières 235: 1-243.

Dortangs, R.W., Schulp, A.S., Mulder, E.W.A., Jagt, J.W.M., Peeters, H.H.G. \& de Graaf, D.T., 2002. A large new mosasaur from the Upper Cretaceous of The Netherlands. Netherlands Journal of Geosciences 81: 1-8.

Elorza, J., Garcia Garmilla, F. \& Jagt, J.W.M., 1996. Diagenesis-related differences in isotopic and elemental composition of late Campanian and early Maastrichtian inoceramids and belemnites from NE Belgium: palaeoenvironmental implications. Geologie en Mijnbouw 75: 349-360.

Felder, P.J., Keppens, E., Declercq, B., Normand, S. \& Streel, M., 2003. Faunal/floral and isotopic responses to Milankovitch precession cycles and environmental changes in the upper Gulpen Formation (Upper Maastrichtian) at the CBR-Lixhe and ENCI-Maastricht bv quarries. Netherlands Journal of Geosciences 82: 275-281.

Felder, W.M., 1995. Historical overview of lithostratigraphic research on the Upper Cretaceous of southern Limburg, the Netherlands. Geologie en Mijnbouw 74: 287-300.
Frank, T.D. \& Arthur, M.A., 1999. Tectonic forcings of Maastrichtian oceanclimate evolution. Paleoceanography 14: 103-117.

Friedrich, 0., Herrle, J.O., Wilson, P.A., Cooper, M.J., Erbacher, J. \& Hemleben, C., 2009. Early Maastrichtian carbon cycle perturbation and cooling event: implications from the South Atlantic 0cean. Paleoceanography 24: PA2211, doi:10.1029/2008PA001654

Gradstein, F., Ogg, J.G. \& Smith, A.G., 2004. A geological time scale 2004. Cambridge University Press (Cambridge/New York/Melbourne): 589 pp.

Hamilton, N., 1990. Mesozoic magnetostratigraphy of Maud Rise, Antarctica. Proceedings of the 0cean Drilling Program, Scientific Results 113: 255-260.

Hess, J., Bender, M.L. \& Schilling, J.G., 1986. Evolution of the ratio of Sr-87 to Sr-86 in seawater from Cretaceous to present. Science 231: 979-984.

Hofker, J., 1961. Die Foraminiferen-Fauna der Gruben Hemmoor und Basbeck. Paläontologsche Zeitschrift 35: 123-145.

Huber, B.T., Norris, R.D. \& MacLeod, K.G., 2002. Deep-sea paleotemperature record of extreme warmth during the Cretaceous. Geology 30: 123-126.

Jagt, J.W.M., 2005. Stratigraphic ranges of mosasaurs in Belgium and the Netherlands (Late Cretaceous) and cephalopod-based correlations with North America. Netherlands Journal of Geosciences 84: 283-301.

Jagt, J.W.M., 2010. Upper Cretaceous and Lower Paleogene in the type area of the Maastrichtian Stage (70.6-65.5 Ma). Berichte-Reporte Institut für Geowissenschaften, Universität Kiel 23: 1-21.

Jagt, J.W.M., Felder, W.M., Dortangs, R.W. \& Severijns, J., 1996. The Cretaceous/ Tertiary boundary in the Maastrichtian type area (SE Netherlands, NE Belgium); a historical account. In: Brinkhuis, H. \& Smit, J. (eds): The Geulhemmerberg Cretaceous/Tertiary boundary section (Maastrichtian type area, SE Netherlands). Geologie en Mijnbouw 75: 107-118.

Jarvis, I., Gale, A.S., Jenkyns, H.C. \& Pearce, M.A., 2006. Secular variation in Late Cretaceous carbon isotopes: a new delta c-13 carbonate reference curve for the Cenomanian-Campanian (99.6-70.6 ma). Geological Magazine 143: 561-608.

Kenter, J.A.M., Fouke, B.W. \& Reinders, M., 1997. Effects of differential cementation on the sonic velocities of Upper Cretaceous skeletal grainstones (southeastern Netherlands). Journal of Sedimentary Research 67:178-185.

Keutgen, N. \& Jagt, J.W.M., 2009. Correlation of Maastrichtian strata in the southeast Netherlands and adjacent regions, northern Germany, northern Spain and the USA. Byulleten' Moskovskogo Obshchestva Ispytatelej Prirody, Otdel Geologicheskii 84: 71-77.

Keutgen, N., Jagt, J.W.M., Felder, P.J. \& Jagt-Yazykova, E.A., 2010. Stratigraphy of the upper Vijlen Member (Gulpen Formation; Maastrichtian) in northeast Belgium, the southeast Netherlands and the Aachen area (Germany), with special reference to belemnitellid cephalopods. Netherlands Journal of Geosciences 89: 109-136.

Lowenstam, H.A. \& Epstein, S., 1954. Paleotemperatures of the post-Aptian Cretaceous as determined by the oxygen isotope method. Journal of Geology 62: 207-248.

Macdougall, J.D., 1988. Seawater strontium isotopes, acid rain, and the Cretaceous-Tertiary boundary. Science 239: 485-487.

MacLeod, K.G. \& Huber, B.T., 1996. Strontium isotopic evidence for extensive reworking in sediments spanning the Cretaceous-Tertiary boundary at ODP Site 738. Geology 24: 463-466.

Martin, E.E. \& Macdougall, J.D., 1991. Seawater Sr isotopes at the Cretaceous Tertiary boundary. Earth and Planetary Science Letters 104: 166-180. 
McArthur, J.M. \& Howarth, R.J., 2004. Sr-isotope stratigraphy: the Phanerozoic ${ }^{87} \mathrm{Sr} /{ }^{86} \mathrm{Sr}$ curve and explanatory notes. In: Gradstein, F., 0gg, J. \& Smith, A.G. (eds): A geological timescale 2004. Cambridge University Press (Cambridge / New York / Melbourne).

McArthur, J.M., Thirlwall, M.F., Chen, M., Gale, A.S. \& Kennedy, W.J., 1993. Strontium isotope stratigraphy in the Late Cretaceous - numerical calibration of the Sr isotope curve and intercontinental correlation for the Campanian. Paleoceanography 8: 859-873.

McArthur, J.M., Kennedy, W.J., Chen, M., Thirlwall, M.F. \& Gale, A.S., 1994. Strontium isotope stratigraphy for Late Cretaceous time - direct numerical calibration of the Sr isotope curve based on the United States Western Interior. Palaeogeography, Palaeoclimatology, Palaeoecology 108: 95-119.

McArthur, J.M., Thirlwall, M.F., Engkilde, M., Zinsmeister, W.J. \& Howarth, R.J., 1998. Strontium isotope profiles across K/T boundary sequences in Denmark and Antarctica. Earth and Planetary Science Letters 160: 179-192.

McArthur, J.M., Howarth, R.J. \& Bailey, T.R., 2001. Strontium isotope stratigraphy: Lowess version 3. Best fit to the marine Sr-isotope curve for 0-509 Ma and accompanying look-up table for deriving numerical age. Journal of Geology 109: 155-170.

McArthur, J.M., Mutterlose, J., Price, G.D., Rawson, P.F., Ruffell, A. \& Thirlwall, M.F., 2004. Belemnites of Valanginian, Hauterivian and Barremian age: Sr-isotope stratigraphy, composition (Sr-87/Sr-86, delta C-13, delta 0-18, Na, Sr, Mg), and palaeo-oceanography. Palaeogeography, Palaeoclimatology, Palaeoecology 202: 253-272.

McLaughlin, 0.M., McArthur, J.M., Thirlwall, M.F., Howarth, R., Burnett, J., Gale, A.S. \& Kennedy, W.J., 1995. Sr isotope evolution of Maastrichtian seawater, determined from the chalk of Hemmoor, NW Germany. Terra Nova 7: 491-499.

Meisel, T., Krahenbuhl, U. \& Nazarov, M.A., 1995. Combined osmium and strontium isotopic study of the Cretaceous-Tertiary boundary at Sumbar, Turkmenistan - a test for an impact vs a volcanic hypothesis. Geology 23: 313-316.

Mutterlose, J., Malkoc, M., Schouten, S., Sinnighe Damsté, J.S. \& Forster, A., 2010. Tex ${ }_{86}$ and stable $\delta^{18} 0$ paleothemometry of Early Cretaceous sediments: implications for belemnite ecology and paleotemperature proxy application. Earth and Planetary Science Letters 298: 286-298.

Nederbragt, A., 1991. Late Cretaceous biostratigraphy and development of Heterohelicidae (planktic foraminifera). Micropaleontology 37: 329-372.

Nederbragt, A.J., Thurow, J., Vonhof, H. \& Brumsack, H.J., 2004. Modelling oceanic carbon and phosphorus fluxes: implications for the cause of the late Cenomanian 0ceanic Anoxic Event (OAE2). Journal of the Geological Society 161: 721-728.

Nelson, B.K., MacLeod, G.K. \& Ward, P.D., 1991. Rapid change in strontium isotopic composition of sea-water before the Cretaceous Tertiary boundary. Nature 351: 644-647.

Niebuhr, B., 2006. Multistratigraphische Gliederung der norddeutschen Schreibkreide (Coniac bis Maastricht), Korrelation von Aufschlüssen und Bohrungen. Zeitschrift der deutschen Gesellschaft für Geowissenschaften 157: 245-262.

Niebuhr, B. \& Joachimski, M.M., 2002. Stable isotope and trace element geochemistry of Upper Cretaceous carbonates and belemnite rostra (middle Campanian, north Germany). Geobios 35: 51-64.

Ogg, J.G., Ogg, G. \& Gradstein, F.M., 2008. The concise geologic time scale. Cambridge University Press (Cambridge / New York / Melbourne): vi + 1-177.
Podlaha, O.G., Mutterlose, J. \& Veizer, J., 1998. Preservation of delta 0-18 and delta $\mathrm{C}-13$ in belemnite rostra from the Jurassic-Early Cretaceous successions. American Journal of Science 298: 324-347.

Schiøler, P., Brinkhuis, H., Roncaglia, L. \& Wilson, G.J., 1997. Dinoflagellate biostratigraphy and sequence stratigraphy of the Type Maastrichtian (Upper Cretaceous), ENCI Quarry, the Netherlands. Marine Micropaleontology 31: 65-95.

Schulz, M.-G., Ernst, G., Ernst, H. \& Schmid, F., 1984. Coniacian to Maastrichtian stage boundaries in the standard section for the Upper Cretaceous white chalk of NW Germany (Lägerdorf-Kronsmoor-Hemmoor): definitions and proposals. Bulletin of the Geological Society of Denmark 33: 203-215.

Sælen, G., 1989. Diagenesis and construction of the belemnite rostrum. Palaeontology 32: 765-797.

Sælen, G., Doyle, P. \& Talbot, M.R., 1996. Stable-isotope analyses of belemnite rostra from the Whitby Mudstone Fm, England: surface water conditions during deposition of a marine black shale. Palaios 11: 97-117.

Smit, J. \& Brinkhuis, H., 1996. The Geulhemmerberg Cretaceous/Tertiary boundary section (Maastrichtian type area, SE Netherlands); summary of results and a scenario of events. In: Brinkhuis, H. \& Smit, J. (eds): The Geulhemmerberg Cretaceous/Tertiary boundary section (Maastrichtian type area, SE Netherlands). Geologie en Mijnbouw 75: 283-293.

Spaeth, C., Hoefs, J. \& Vetter, U., 1971. Some aspects of isotopic composition of belemnites and related paleotemperatures. Geological Society of America Bulletin 82: 3139-3150.

Sugarman, P.J., Miller, K.G., Bukry, D. \& Feigenson, M.D., 1995. Uppermost Campanian-Maestrichtian strontium isotopic, biostratigraphic, and sequence stratigraphic framework of the New Jersey coastal plain. Geological Society of America Bulletin 107: 19-37.

Van de Schootbrugge, B., Föllmi, K.B., Bulot, L.G. \& Burns, S.J., 2000. Paleoceanographic changes during the Early Cretaceous (ValanginianHauterivian): evidence from oxygen and carbon stable isotopes. Earth and Planetary Science Letters 181: 15-31.

Van de Schootbrugge, B., McArthur, J.M., Bailey, T.R., Rosenthal, Y., Wright, J.D. \& Miller, K.G., 2005. Toarcian oceanic anoxic event: an assessment of global causes using belemnite $C$ isotope records. Paleoceanography 20: PA3008, doi: 10.1029/2004PA001102.

Veizer, J. \& Fritz, P., 1976. Possible control of post-depositional alteration in oxygen paleotemperature determinations. Earth and Planetary Science Letters 33: 255-260

Vonhof, H.B. \& Smit, J., 1996. Strontium-isotope stratigraphy of the type Maastrichtian and the Cretaceous/Tertiary boundary in the Maastricht area (SE Netherlands). In: Brinkhuis, H. \& Smit, J. (eds): The Geulhemmerberg Cretaceous/Tertiary boundary section (Maastrichtian type area, SE Netherlands). Geologie en Mijnbouw 75: 275-282.

Vonhof, H.B. \& Smit, J., 1997. High-resolution late Maastrichtian-early Danian oceanic Sr-87/Sr-86 record: implications for Cretaceous-Tertiary boundary events. Geology 25: 347-350.

Weiss, W., 1999. Foraminiferal biostratigraphy of the marine Maastrichtian in northern Germany. In: Schulp, A.S., Jagt, J.W.M. \& de Graaf, D.T. (eds): $150^{\text {th }}$ anniversary of the Maastrichtian Stage: a celebratory conference. Natuurhistorisch Museum Maastricht, 17-21 November 1999, Conference programme, abstracts and field guide: 58-59. 